\title{
Induction and Deduction in Theorizing of International Relations
}

\begin{abstract}
The article presents the ways of understanding the place of induction and deductive reasoning in the process of building the theory and knowledge of international relations and the resulting disputes present in the International Relations.

The author argues that in the study of international relations, as in the natural sciences, it is necessary to combine empirical observation with creative building of theory.

The author performs a critical analysis of the positions of selected theoreticians of international relations on issues related to the problems of induction and deduction and theorizing of international relations.
\end{abstract}

Key words: induction, deduction, theory, International Relations

$\mathbf{T}$ his article attempts to assess neither researchers of international relations who prioritize the collection of empirical materials, convert them into data, and test hypotheses and support "empiricism" at the expense of theorizing, nor those who put deduction first. I prefer to present ways of understanding of induction and deduction, used in the study of international relations, in the process of building theory and knowledge about international relations and relevant disputes. I argue that in the study of international relations, similarly to natural sciences, it is necessary to combine empirical observation and creative theory building.

\section{$* * *$}

In the international relations, there is a broad consensus regarding the usability of theory in producing knowledge about international politics. Disputes, however, concentrate on the course of theory building. Theory building is often considered to be a kind of art, and it is also placed in the deductive-nomological model, in the discovery phase, during which no specific rules are applicable, since the phase is based on intuition and creativity. There is literature dealing with criteria formulated by theory testing that should be used to determine which of the theories is better [Waltz, 1979 (2010), pp. 13-17; King, Keohane, Verba, 1994, pp. 99-114). However, the path from interest in major international politics issues to detailed arguments which explain or interpret specific aspects of the politics remain mysterious. How should we approach the relationship combining empirical data representing "real world" developments of our interest with theories that we use to explain the former? (Blagden, 2016, p. 196).

It can be proven that deductive reasoning is an important component of the effort to discover the truth while building a theory, as it is important to recognize the role played by 
induction as a way of finding the "departure point" for the theorization process. Deduction can be defined as a top down reasoning in which a conclusion is a logical necessity that results from subsumption of what is explained according to a general rule. The reasoning pattern e.g. "if all $p$ 's are $q$ and all $r$ 's are $p$ 's, then $r$ 's are $q$ 's" is a deductive argument. On the contrary, induction is a bottom up process, in which a conclusion is a generalization or extrapolation resulting from input information collected by a researcher. Therefore, the pattern of reasoning in the following form: "of the majority of $p$ 's are $q$ 's and $r$ 's are $p$ 's, there is a high probability that $r$ 's are $q$ 's", is an inductive argument.

Frequently, advocates of deduction, who refuse induction any practical sense as a component of theorization, at the same time support empirical testing of theoretical assumptions. Thus, they open doors for induction. The reason is that the empirical material collected is usually a basis for selecting new theoretical ideas. Advocates of induction in the study of international relations prioritize collection of data, testing hypotheses and "naive empiricism" over theory building (Blagden, 2016, p. 196). However, even if the theory is given an explanatory priority, the role of inductive and deductive reasoning needs to be thoroughly examined.

\section{***}

The broadly understood science of culture, like nature sciences, are very much empirical. Regardless whether we support the explanatory theory or the interpretative theory, we need to operate within the framework defined by the theory and empirical material. Therefore, we should be aware of the relationship between the international political theory and the empirical material and vice versa. This will enable to demystify the theory building process, and thus it should broaden the ability to implement the goal and reveal the nature of the theory and underlying criteria that can be used to assess its value.

We usually believe that researchers developing explanatory theories attempt to identify cause-effect based processes leading to hypothetical international outcomes. At the same time, supporters of the interpretative theory, as they believe, aim at the same goal. Therefore, regardless our own position, it is unjustified to refuse supporters of an opposite idea a scientific dimension. The mere fact that a supporter of the explanatory theory believes that it is possible to detach objects from the cognizant subject (dualism) and the person acclaims neo-positivistic epistemology and critical/scientifically realistic ontology does not mean that the person rejects the interpretative theory. The latter, while trying to understand the world, also continuously manoeuvres between theoretical concepts and the empirical material, although he/she concentrates on revealing specific contexts rather than general patterns.

Arguments that I am referring to have been raised by researchers of post $2^{\text {nd }}$ World War international relations, who supported inductive or deductive reasoning. I believe that it is worth commencing the analysis with the presentation of a more fundamental and, at the same time, ambivalent position by Hans J. Morgenthau, who devised a number of theses on the role of theories based on his assumptions on the nature of international politics. He emphasised that any theory requires a lead notion and such a notion for international relations is power. Without that notion, we basically have some sort of 
a photograph presenting everything that we can see with our naked eye. However, a photograph is by far less useful than a painted portrait which shows just one thing, which remains invisible for a naked eye, namely the "rational essence of an object" (Morgenthau, 1959, p. 17). The path to develop a theory is beset by a number of obstacles. The most important one, referred to by Morgenthau, is the "relativist concept of a man and society" which contradicts the "existence and possibility to understand objective general truths about the political sphere." Such a relativism reduces the empirical analysis "to the mere description of an ephemeral historic situation" or a normative theory, which "becomes indistinguishable from political ideology." The inability to reveal all typical and similar facts pertaining to every historical situation makes it possible for us that "we can only play by ear and must be satisfied with a series of hunches which may or may not turn out to be correct." Finally, Morgenthau weakened his agnosticism by claiming that "the truth of political science is of necessity a partial truth" (Morgenthau, 1959, pp. 18-21).

In his article on "Theorizing about theory" of 1960, J. David Singer concluded that even if our scientific effort concentrates on gathering empirical data, its ultimate goal should be the development of theory. This requires that we formulate specific hypothesis that can be tested. The hypothesis should be explicit, and terms used in them must be unambiguous, the independent and dependent variables must be well-defined and grounded in empirical data, whereas casual or correlative relationships logically interconnected. It is also advisable to treat empirical data as a particular case in a general class of cases, all of which have something in common. This does not suggest that we should assume that all cases within their class are homologous, but indicates that the search for analogy and comparison is the most fruitful way of converting isolated research at a low level of generalization into work of theoretical significance (Singer, 1960, pp. 440-441).

According to J. D. Singer, the period of 1955-1965 in the disciplinary history of international relations was a decade of growing awareness that the inductive path to theory must have its beginning in data, whereas the deductive path, to step beyond speculations, must adopt empirical assessment as its success factor. At the same time, Singer argues that the difficulty of converting facts into data is that they differ depending on the object of the study. In international relations, the difficulty is significant, since mere gathering of credible facts requires overcoming various obstacles, e.g. confidential information and their distortion by governments, as well as distribution of such facts in time and space (Singer, 1965, p. 69). In his iconic article on the analysis of international relations, while considering the level of the nation-state, Singer emphasised that every description of the behaviour of the state in a given international situation should be considered highly incomplete, if it disregards relations between external forces having influence on that state and its behaviour in foreign affairs. Although we may observe correlations between all types of forces in the international system and behaviour of states, they casual relations may have deductive and hypothetical nature until we perform empirical studies that reveal mechanisms connecting those forces and behaviours. Even if we accept incomplete capability to describe a "non-phenomenological" (deductive) model, we must refer to it, if we want to make progress in our explanations. Singer also refers to an opposite position which questions the usability of the deductive model and assesses it as a result of a misunderstanding of the nature explanation in social sciences. In his opinion, there 
is no need to consider all relations between stimuli and reaction to explain the behaviour of a state or any other grouping of people. In his opinion, it is unjustified to believe that empirical observation, a frequent source of errors, provides better explanation than deduction or analogy. If we agree that gathering data is inefficient, we should abandon it (Singer, 1961, pp. 87-88). Finally, the position presented by Singer regarding the use of induction or deduction in the study of international relations is ambivalent, similarly to H. J. Morgenthau; However, it is so chiefly for methodological reasons. On the one hand, under the influence of the behavioural revolution in the discipline, Singer points to pressure to introduce more empirical studies that involve data gathering and hypothesis testing as a precondition for building a theory. On the other hand, "Even if we were to declare a moratorium on deductive and speculative research for the next decade, and all of us were to labour diligently in the vineyards of historical and contemporary data, the state of international relations theory would probably be no more advanced at that time than it is now, unless such empirical activity becomes far more systematic" (Singer, 1961, p. 92). "Systematic" is used here to indicate the cumulative growth of inductive and deductive generalizations into an impressive array of statements conceptually related to one another and flowing from "some common frame of reference." Although Singer does not specify what could be the frame of reference, he is convinced that one must exists. I believe that Singer had a problem with indicating such a frame sine he favoured the inductive way of building a theory and understanding it as a set of rules. Otherwise, such a frame of reference should consist of a semantically understood theory. He indirectly admits that without a theory, empiricism may provide a set of disparate, non-comparable and isolated bits of information or extremely low level generalizations. Thus, such an empiricism may little contribute to the development of the theory of international relations.

In international relations, issues raised by J. D. Singer have become the subject of particular attention of Kenneth Waltz [1979 (2010), 1986, 1997, 2003]. In his Theory of International Politics, published in 1979, K. Waltz provided an important definition the academic research on international relations that lasted for many years. Scholars who presented competitive propositions felt obligated to ponder on Waltz's theoretical preferences. Ole Waever considered the Theory to be the most influential books in the history of the discipline (Waever, 2009, p. 201). The influence applied to two basic aspects of the study of international relations. The first one of them was related to the Waltz's proposed international political theory in the form of structural realism and constituted a basis for his merit-based position on substantive assessments of international politics. The second one, which is actually the object of my interest, applied to Waltz's opinions on selected issues related to philosophy of science and their meaning in the study of international relations (Waltz, 1979, pp. 1-17).

The Waltz's publication set a pattern for theoretical studies and theory building, which influenced not only the form of political realism, but also competitive approaches, such as liberalism, constructivism and reflectivism. It is ironic that researchers of international relations did not put much attention to the analysis of the Waltz's position on the nature of theory (Waever, 2009, p. 201). The first chapter of Theory entitled Laws and Theories is a kind of a "miniature treaty" on what the international political theory is, how it is created and what role it plays in the studying of international politics. A particular influ- 
ence of Waltz in the discipline was connected to analytical promises to be delivered by his deductive reasoning. Waltz seemed to offer a process resulting in the transformation of the discipline into the "true" science by creation of logically coherent, strong, frugal and test-worthy theories about the functioning of international politics, and then testing their explanatory power through empirical observation in a similar fashion to researchers of natural sciences.

Discussions inspired by the Theory focused on various aspects of the Waltz's proposition. Initially, it was a theoretical debate on realism vs liberalism. In time, the debate became increasingly internal encapsulated within political realism (offensive/defensive realism; neoclassical realism, post-classical realism). At the meta-theoretical level, discussion on the social theory, especially the issue of the agent - structure evolved into the discussion on the method to examine a society and problems defined as individualism/holism; materialism/idealism or explanation/understanding were considered to be the most important for the discipline. Those issues became central for discussions initiated by constructivism and embodied in propositions by Alexander Wendt in his Social Theory of International Politics (1999). Regardless the above, the philosophy of science did not play a major role in the discussions. An exception was the discussion on the Methodology of Scientific Research Programs by Imre Lakatos (1970, 1995) introduced to international relations by John A. Vasquez $(1997,1998)$ and continued chiefly by Colin and Miriam F. Elman (1997). The introduction to the book edited by the Elmans and entitled Progress in International Relations Theory (2003) dealt with the theory testing and was written by K. Waltz (2003).

Researchers of international relations do not describe $\mathrm{K}$. Waltz position on this issue in an unambiguous manner as regards the philosophy of science that he accepted. It is partially the result of the fact that although Waltz emphasised its key importance for theorizing, he did not present a scholastic position as regards the choice of one out of several philosophical propositions. He rather chose propositions formulated by various science philosophers that were considered to belong to different philosophical camps. Thus, his philosophical position is associated with positivism, popperism, pragmatism, instrumentalism and scientific realism (Waever, 2009, p. 203). Paradoxically, although Waltz is most often considered to be a positivist, such a designation seems to be the least accurate. Suffice it to refer to the fundamental criticism of induction as a way of building a theory, which is expressed by Waltz in meta-theoretical chapter Theory. Following Claud Lévi-Straus, he terms it "inductivist illusion." Waltz criticises any attempt to build a theory by accumulating more data and looking for correlations and applying simple theory testing methods, as if they were real beings, and not theoretical imaginations (Waltz, 1979, p. 4). At the same time, we should remember arguments referred to by Waltz to justify his position, namely that the development of a good theory is not possible through induction, if it is to tells us what actually guides international politics. Those arguments include more nuances in his own scientific conduct than many supporters of his position could ever notice and admit (Blagden, 2016, p. 196). However, the comment to the Waltz position formulated by David Blagden does not seem to be accurate. He stated that by rejecting induction, as a method that is not able to reveal the "objective reality," Waltz forgets that he has postulated himself to assess the value of a theory by the way it explains phenomena that take place in the real world. Waltz 
distinguishes between the building of a theory and its testing. To understand the scientific conduct, according to Waltz, it is crucial to be certain that its core idea is to create theories that are worth testing.

Therefore, as regards the building of theories, the main Waltz's goal is to criticise the prevailing position that theories should be built using inductive methods. It has been expressed in Waltz understanding of theory. As a result, he rejects the definition of a theory as a set of laws pertaining to a particular behaviour or phenomenon (Waltz, 1979, p. 2). Such an understanding of theory is typical for representatives of natural sciences. Although theories are more complex than laws, the difference is quantitative only. The definition expresses scientific aspiration of representatives of social sciences who want to build theories by collecting carefully verified, interconnected hypotheses. Waltz doubts the use of such a method, since even if we determine a correlation between dependent and independent variables, it does not mean that there is a causality between them. The relationship devised from correlation can be real or apparent (Waltz, 1979, p. 3).

Yet another problem is more important and more difficult to solve. The essence of it is the following: even if we are convinced that the correlation indicates the existence of a credible relationship, we still miss its explanation. Correlations expressed in numbers may describe processes taking place in the world, but no matter how securely we nail a description down with numbers, we still have not explained what we have described. "Statistics do not show how anything works or fits together. Statistics are simply descriptions in numerical form. The form is economical because statistics describe a universe through manipulation of samples drawn from it. Statistics are useful because of the variety of ingenious operations that can be performed, some of which can be used to check on the significance of others. The result, however, remains the description of some part of the world and not the explanation of it. Statistical operations cannot bridge the gap that lies between description and explanation" [Waltz, 2010 (1979), p. 11]. Finally, although information gained can be useful, we have still not discovered its theoretical meaning.

The faith that the truth can be won and explanation achieved through the accumulation of more and more data and the examination of more and more cases is referred to by K. Waltz as "inductivist illusion." It is illusion, since data do not speak for themselves, whereas observation and experience never lead directly to knowledge of causes. Induction enables us to touch fragments of problems only. The belief that pieces can be added up, that they can be treated as independent variables whose summed effects will account for a certain portion of dependent variable's movement rests on nothing more than faith. We do not know what to add up and we do not know whether addition is the appropriate operation. The number of pieces that might be taken as parts of the problem is infinite, and so is the number of ways in which the pieces can be combined (Waltz, 1979, p. 4).

While referring to the attachment of the then researchers of international relations to induction, Waltz means supporters of quantitative methods and the behavioural approach. They assume that by analysing numerous cases they can reveal correlations and patterns representing "reality that is out there." Waltz argues that we can never be sure that the status of things we discovered through inductive methods corresponds with something real. What we think of as reality is itself an elaborate conception constructed and reconstructed through the ages. "Reality emerges from our selection and organization of materials that are available in infinite quantity. How can we decide which materi- 
als to select and how to arrange them? No inductive procedure can answer the question, for the very problem is to figure out the criteria by which induction can usefully proceed. [...] Since empirical knowledge is potentially infinite in extent, without some guidance we can know neither what information to gather not how to put it together so that it becomes comprehensible. If we could directly apprehend the world that interests us, we would have no need for theory. We cannot. One can reliably find his way among infinite materials only with the guidance of theory" (Waltz, 2010 (1979), pp. 12-13).

Theories are something else than mere collections of laws. Theories are statements, Waltz claims, that explain them. Theories are quantitatively different from laws. Laws identify invariant or probably associations. Theories show why those associations exist. Theories, apart from descriptive notions, which are included in laws as a result of observation or laboratory procedures (we can speak of law when it passes observation or experimental tests) - contain primarily theoretical notions. Theories cannot be built through an inductive procedure, since theoretical notions are constructs which are coined rather than discovered. Waltz illustrated it while referring to the advancement from Aristotle through Galileo to Newton. The advancement based on departing from the real world and common experience and building increasingly far reaching theoretical notions (natural state of rest, constant circular motion, point mass, momentous acceleration, force, absolute time and space). Theoretical notions do not explain or predict anything. They are neither true not false. They find their justification in the success of the theory that employ them. Of purported laws, we ask: Are they true?". Of theories, we ask: "How great is their explanatory power?" (Waltz, 1979, p. 5). Since the law does not explain why a certain relationship exists, we need a theory. In order to go beyond "observational facts" we need to face the problem of explanation which is the domain of theory. Waltz quotes Albert Einstein who once said that "theory can be tested by experience, but there is no way from experience to the setting up of a theory" (Waltz, 2010 (1979), p. 15).

This does not mean that Waltz encourages to reject induction. However, he is convinced that the inductive procedure leads to "theoretical dead end," and encourages to ask the following question: What is and what is not achievable using the method? He points to the usability of induction at the level of hypotheses and laws, rather than a theory. Hypotheses can be derived from a theory, and if we succeed to confirm is beyond any doubt we call them laws. It is possible to arrive at the same through induction. And in this instance too, if we confirm them beyond any doubt, they become laws. However, hypotheses regarding correlations between phenomena, even if proved empirically, do not lead to setting up a theory. Relationships we discover between phenomena neither offer any explanation themselves not suggest it unambiguously. Although induction leads to a "theoretical dead end," before we nevertheless need some sense of the puzzling connections of things before we can worry about constructing a theory. At the same time, we need to know what kind of data or correlations we are looking for, and thus we need theories which can guide us. "Knowledge must precede theory, and yet knowledge can proceed only from theory" [Waltz, 2010 (1979), p. 15].

If it is not possible to proceed from the law to a theory and from hypotheses to their explanation, Waltz considered pondering on correlations between them futile. If induction is not the way to get onto useful track, what is? We should rather ask ourselves the following questions: Why does this occur? How does that thing work? What causes 
what? How does it all hang together? [Waltz, 2010 (1979), p. 16]. To answer these questions, we need a theory. According to Waltz, theory is fruitful because it goes beyond the necessarily barren hypothetico-deductive" approach. "Both induction and deduction are indispensable in the construction of theory, but using them in combination gives rise to a theory only if a creative idea emerges" [Waltz, 2010 (1979), p. 18]. While commencing the examination, we need to pose theoretical questions.

$$
* * *
$$

Thinking about a theory is often trapped in the traditional distinction between empirical (positive) versus normative theory; critical versus theory of problem solving and explanatory theory versus interpretative theory. The conclusiveness of such distinctions is at best doubtful. All empirical theories contain normative assumptions and all normative theories are based on empirical statements. The purpose of critical theories is to contribute to social freedom and justice, but problem solving theories can also contribute to the implementation of these goals as well. Explanatory theories are attempts to answer the question "why," whereas interpretative theories answer the question "how." However, almost always questions "how" and "why" are connected and the answer to one of them helps to answer the other one and vice versa (Reus-Smit, 2016, p. 428). The problem with theory extends, however, beyond doubts related to inconclusiveness of routine dichotomies. The types of theories simply do not exhaust various forms of theories and ways of theorizing in the contemporary international relations.

It is worth asking whether Waltz's position toward induction and deduction and the postulated creative-deductive way of theorizing in the study of international relations are still valid forty years later or they need to be significantly modified? Firstly, the influence of the Waltz's proposition can be easily seen in foundation texts describing competitive approaches toward a structural realism in the study of international relations. The proposed by Waltz system approach to international politics has been used by liberal institutionalism (Keohane, 1984, pp. 25-30). Also constructivism, in particular in its moderate variation represented by Alexander Wendt, accepts the Waltz's understanding of the essence of theorizing and the role of inductive and abductive reasoning. According to Wendt, constitutive theories are still theoretical. They can be used for drawing conclusions from observed occurrences to wider patterns, regardless whether they are inductive, leading to generalization based on a set of occurrences, or abductive reasoning that set certain base structures, which take account of such occurrences. In no case, data do not speak for themselves. It means, as emphasised by Wendt, that constitutive theories are the foundation to formulating hypotheses about the world which can and should be tested (Wendt, 1999, p. 87).

Secondly, numerous examples of valuable theorizing in the study of international relations still accept the Waltz's deductive ideal of theorizing, even though they are firmly based on inductive grounds. For example, while constructing his rational theory of international politics, Charles Glaser indicates that making an important decision on which variables are to be taken into consideration necessitates a deductive theory. In essence, its goal is to build such a deductive theory (Glaser, 2010, p. 6). Another example is of- 
fered by the paper by Nuno Monteiro (2014) on the unipolar theory of international politics. Monteiro criticises a research approach involving solely gathering of data and testing hypotheses in a situation of a shortage of creative theorization.

For twenty years after the publication of Waltz's Theory, the Great Debate played a pivotal role in the study of international relations. This situation, however, triggered a reaction and the pendulum started moving towards empirical research. In the past ten years, it led to a pressure on conducting research with the main goal of identifying causalities. Unfortunately, it is difficult to answer questions that require the theory of international relations - for example, questions about relationship between polarity and stability of an international system, about causes of great wars, about sources of international changes, about inequality in international relations - using experimental methods or quantitative studies, such as large- $N$ (Monteiro, 2014, pp. 17-24).

Thirdly, the cautious approach postulated in the political science regarding the selection of dependent variables (variable which is subject of examination) - as advised in the book by Gary King, Robert O. Keohane and Sidney Verby (1994, pp. 107-109) which had crucial influence on the methodology of examination - strengthened the nomological-deductive model in IR. Of course, we should not disregard the postulated approach. The concern about generalization based on a biased set of cases is justified. However, if we treat is it in an excessively absolutist manner, it may have a dramatic effect, and researchers may be afraid of criticism about setting up theories based on moving from interesting observed cases and empirical patterns to theorizing. Such a position results in a domination of "purely" deductive theorization, even if induction was a major element of the examination (Blagden, 2016, p. 201).

The most important consequence of the Waltz's position is the dissemination of belief that the goal should be to gain "economical" and general knowledge, rather than examining details of specific cases of international politics. The examination should produce knowledge about multitude of things that are the most important. Waltz argues that we will not implement the goal of we follow the induction procedure. While doing so we can only deal with "fractions of problems." "The belief that pieces can be added up, that they can be treated as independent variables whose summed effects will account for a certain portion of dependent variable's movement rests on nothing more than faith. We do not know what to add up and we do not know whether addition is the appropriate operation. The number of pieces that might be taken as parts of the problem is infinite, and so is the number of ways in which the pieces can be combined" [Waltz, 2010 (1979), p. 12]. This type of thinking is not supported by King, Keohane and Verba in their book. However, they wrote that since interesting research problems of social sciences cannot be given the form of hypotheses that enable their statistical testing, "we do not encourage the sole use of quantitative methods." They claim that non-statistical research could produce more reliable results if researchers pay attention to rules of scientific inference - rules that are sometimes more clearly stated in the style of quantitative research. They are aware that rules of inference they discuss (descriptive and causative) are not appropriate for all research problems in social sciences. They are aware that many significant questions about political life expressed in such notions as agency, obligation, legitimacy, citizenship, sovereignty and the proper relationship between national societies and international politics are philosophical rather than empirical. They argue, however, that "rules are relevant 
to all research where the goal is to learn facts about the real world" (King, Keohane, Verba, 1994, p. 6). The position expressed by Waltz is, however, more sophisticated. Waltz questions the purpose of examining many cased with the hope that correlations and patterns may emerge and reveal „reality that exists." We say that "we can never say with assurance that the state of affairs inductively arrived at corresponds to something objectively real." It is so, since "what we think of as reality is itself and elaborate conception constructed and reconstructed through the ages. Reality emerges from our selection and organization of materials that are available in infinite quantity. How can we decide which materials to select and how to arrange them?" [Waltz, 2010 (1979), p. 12].

Despite is undeniable attractiveness and simplicity, the Waltz's proposition may raise doubts regarding its disposition to creative and deductive set up of a theory before it is tested regarding its explanatory power. The essence of the doubt is that until we refer to what Waltz calls "reality that is out there," we do not have any idea that could tell us what is actually worth theorizing. We know neither our theoretical goals not how to construct analytical notions that could comprise the core of the theory. We also do not know how to set boundary conditions for our theoretical goals. Colin Wight's advice is the following: conceptualization is a precondition for empirical research and researchers must have an idea of what they try to explain and how to do it in the best way possible - however, it does not seem to be of much use (Wight, 2002, p. 35). Every examination starts with certain assumptions and understanding of their essence is a major part of the research.

Waltz argues that theorizing means primarily remove things and formulate bold simplifications. If theories do not do that, they are not theories. Theories are about something not about everything. Explanation always combines theory and knowledge which extends beyond theory. Waltz argues that although theory enables to formulate predictions, but to explain "something" that happens in the real world it is necessary to know "something" about the world (Halliday, Rosenberg, 1998, p. 380). A similar position on the issue has been presented by John Mearsheimer who claims that the ultimate test of each theory is how well it explains occurrences in the real world. "By doing so," theory provides a handsome and intuitively attractive summary of the "mainstream" approach to predictive accuracy (Mearsheimer, 2001, p. 6).

A number of researchers of international relations doubt the deductive capability of theory. Adam Humphreys (2011, pp. 257-277) points to unavoidable problems with "quasi-deductive" theorizing. Supporters of explanatory theories often insist that their theories are useful, even though they cannot be deductively applied. Humphreys argues that explanatory theories are typically heuristically applied. Accounts of "specific empirical episodes" are shaped by their theories' thematic content, but are not inferred from putative casual generalizations or covering laws. If it is so, it subverts the nomotheticidiographic distinction between explanation and description. If theoretical ideas influence our thinking about international relations, the key question is how they translate into substantial judgements about specific empirical episodes. Theories do not consist of laws, but indicate the type of explanation required, provide conceptual categories and suggest what is empirically most important (Humphreys, 2011, pp. 257-258). We may refer to numerous opinions of researchers of international relations stressing that explanatory theories essentially are not used deductively. For example, Peter J. Katzenstein $(1996$, p. 26) proves that even though neorealism promises a strict deductive 
theory, it cannot be applied directly to issues related to national security, and thus it can be used as "orientation framework." Robert Jervis (1999, p. 43) suggests that neorealism and neoliberalism can be better described as schools of thinking or approaches rather than theories, and they miss cohesion that enables falsification. Emanuel Adler (1997, pp. 328-329) believes that constructivists aim at explaining the social construction of reality, but their reasoning cannot be compared with deductive proof or inductive generalization models. Friedrich Kratochwil (1993, p. 66) argues that although most political scientists still pay lip service to the nomothetic/deductive explanation schemes, "no general social laws have been discovered." John G. Ruggie (1998, p. 861) believes that no theory of international relations meets criteria of a subsumption model covering law model. Moreover, the majority of theoreticians do not question the assessment. Finally, we may believe that the usability of deductive theories is based on something else than their capability of deductive generation of explanations.

David Blagden summarises the argument suggesting that neither positivist Mearsheimer's position not Humphreys' critical perspective do not say anything how to set up a valuable theory that could present primarily major patterns or occurrences. Thus, regardless how people creating a theory try to avoid induction from observable occurrences and how much creativity is shown in building a theory, the only way leading to interesting questions about the world, which can be transformed into the theory of international relations, is to observe empirical phenomena and deciding whether they result from a relationship which is significant enough to become a subject of theorizing. Therefore, it seems that there is no other way but to object a mere testing of hypotheses and accepting a position that creative deductions are the clou of the theory generation process on the one hand, and continue the recognition and examination of empirical puzzles which necessitate theorizing on the other (Blagden, 2016, p. 9).

The thesis of democratic peace may be a particularly illustrative example of combination between induction and deduction while building a theory. Undoubtedly, the theory of democratic peace, regardless its form, has its roots in the stunning empirical regularity and general Kant's observations. Regardless we accept the Jack Levy's argument (1989, p. 88) that the thesis is the closest to the empirical law of all theses formulated in the study of international relations. It stems from empirical (historical) data. Despite numerous controversies regarding their value (Maoz, Russett, 1993; Oren, 1995; Farber, Gowa, 1995), empirical data are the foundation of various theoretical approaches attempt to indicate causes hidden behind the observed empirical pattern. Theoretical approaches have provided additional stimuli to more advanced empirical tests. One may believe that this type of a relationship between theory and data shows a mechanism which can legitimize our understanding of international relations. It illustrates the thesis that neither hypothesis testing not mere theorization should not dominate studies of international relations. Alexander George and Andrew Bennett (2005, p. 12), while criticizing the position expressed by King, Keohane and Verby (1994), argues that if we examine inductively interesting historical cases, we will never be able to move from the logic of testing to the logic of discovering, or to formulating new hypotheses. The use of induction can be "dense," as it is in the empirical research scheme, while being aware of the deductive element of building effective theory or "thin," as in a deductively focused research scheme, where empirical puzzles are used only to identify a problem and formulate research questions. 
Therefore, it seems that we have a sort of continuum between induction and deduction understood as ideal types. Additionally, if we agree that a question-based research approach is a more appropriate way to find answers to substantial problems of international politics than having "great debates" on fundamental problems of the discipline, then the fusion between induction and deduction in the research process leading to the theory of international relations seem unavoidable. Also K. Waltz accepted the above process. In his article Evaluating Theories, while following Errol Harris, Waltz emphasises that our perception also counts in hypothesis testing. The assessment of a theory necessitates moving "back and forth" between implications of that theory and uncertain status of matters which we believe to be the reality against which the theory is tested (Waltz, 1997, p. 916). While recognizing that the international political theory should be assessed only against its explanatory power and that induction is a necessary addition to creativity that helps us finding a starting point for building of a deductive theory, we may also understand that induction has a major instrumental value from the beginning of the theory building process, regardless whether it is capable to reveal "objective reality."

\section{***}

It seems that the majority of international relations theoreticians considers that a theory and data are correlated in a feedback-like fashion. Thus, the understanding of both theory and data is possible through comprehension of their correlation mechanism. The building of a test-worthy theory of international relations requires awareness that the process necessitates deduction and induction which should precede one another. We should know what is empirically interesting before we start looking for causalities and develop understanding of the causal order before we assess particular occurrences. If we consider the procedure to be appropriate, the Waltz advice to be sceptical about induction, since we cannot use it to discover the "objective reality," does not appreciate the fact that the value of every theory of international relations should be assessed depending on how well it explains occurrences in the "real world" (Blagden, 2016, p. 197).

If the dispute regarding the role of induction and deduction in the study of international relations is resolved in the spirit of the necessary correlation between empirical observation and creative building of theory, it may contribute to the development of the discipline. Similarly, like in natural sciences, we treat an effect as a starting point for the development of theory. The explanatory power of such a theory is tested with a conviction that effects observed matter. The progress in explaining of the world can also be achieved through explaining of particular occurrences and their effects. R. Harrison Wagner argues that the science explains not only regularities but unique cases as well. An example is the question about the origin of HIV, if it originates from chimpanzees, then how it was transmitted to from animals to people? It would be an absurd to treat such research as an example of a "small-n" study that can be expanded by enlarging the sample. In this particular case, we have been trying to formulate good explanations of what happened, and then check a number of facts that are explained (Wagner, 2007, p. 6). From a practical point of view, contradicting the usability of induction as a way to generate a "starting point" to deductive theorizing is a madness leading to a priori 
theorization (Blagden, 2016, p. 14). A researcher should also remember that deduction is tautological in its nature. It preserves truth included in its premises, but does not explain anything, since its result is a logical consequence of initial assumptions. The mere fact that an argument is valid means only that the conclusion must be true if premises are true. However, even though certain facts, known to be true, can be derived from explanation, this does not mean that there is no other explanation which is more valid regarding all known facts. As emphasised by K. Waltz: deduction „may give certain answers, but nothing new; what is deduced is already present either in theoretical major premises or in empirical minor premises dealing with matters previously observed. [...] Both induction and deduction are indispensable in the construction of theory, but using them in combination gives rise to a theory only if a creative idea emerges" [Waltz, 2010 (1979), p. 18].

Waltz's argument does not require us to reject a methodological regime. However, the combination of induction and deduction in setting us a theory has its limitations. For example, it is obvious that if we use data alone as a starting point to develop a theory and then to test it, we can be accused of making a methodological mistake. In any scientific discipline, models can be internally cohesive, but they may lack necessary or sufficient correlation with the "real world." As the contemporary economics teaches us, in particular macroeconomics, economists strive to create scientific models that comply with deductive cohesion and requirements. However, economic systems are dynamic and non-linear. It means that results of processes are susceptible to even minor changes of initial conditions. Moreover, economic systems are reflective, which means that the conviction about results influence results themselves. Undoubtedly, the comments apply to international systems as well. All sciences use unrealistic, simplified assumptions (idealizations), since it is very difficult to examine everything as the same time. However, to make such a model practical, we need to be ready to account for previously neglected factors. Additionally, such modifications are important for some problems, for others not. For example, air resistance makes no difference for a falling feather, but for a falling bullet does. Every model can be "calibrated" against the real world. However, such a correspondence not necessarily legitimizes the model. Successful strategies in such models are the product of assumptions made by their creators. As Donald Davidson, a philosopher of analytical tradition, argues (2000, p. 66), it might be natural to think that there is a single description of things which reveals their essential nature, a true description of the world, a description of "reality as it is". However, no such a description or "interpretation" exists in any of known languages.

Therefore, we should a priori reject the idea that it is possible to describe the world of international relations using a universal model in which all key relations are predetermined. International politics is defined by people, their cultures and technologies. Consequently, it evolves which is not accidental, however, it escapes its full description. We must reduce our expectations perhaps to specific contexts only (Kay, 2012, p. 95).

Examining theses using empirical data enables to define the explanatory power of theory. If a theory is strong it helps a researcher to identify new empirical data. The iteration of the cycle improves our theories. It is an iterative process in which we should not be concerned what came first the "chicken" (deduction) or the "egg" (induction). The majority of researchers studying international relations seem to accept that type of thinking while conducting their research. If they are capable of recognising that occurrences 
and puzzles observed may lead to specific theoretical problems, the explanatory power of a theory they develop can be greater. At the same time, we should remain humble in our approach to explanation. Our understanding of social phenomena will never be complete, whereas regarding generalization and building of theoretical abstract notions we unavoidable loose major causalities. Similarly, like representatives of other disciplines, researchers examining international relations never formulate "correct answers," but develop models, which more or less precisely describe certain aspects of the reality. Once a statement is made it is never finite, but it is a mere pause in the never ending process of theory development (Blagden, 2016, p. 17).

For some researchers deductive reasoning is a trade mark of science, whereas induction, in which an argument is derived from the object examined, is treated as a literary history or criticism method (Kay, 2012, p. 96). This distinction, however, is not legitimate. The majority of scientific advancement is based on induction. Most often, empirical regularities are observed before a clear understanding of underlying mechanisms. The truth also applies to natural sciences, physics included. Any models of international politics developed by researchers are going to be mere abstractions. A map will never be the territory.

\section{Bibliography}

Adler E. (1997), Seizing the Middle Ground: Constructivism in World Politics, "European Journal of International Relations", vol. 3, no. 3.

Blagden D. (2016), Induction and Deduction in International Relations: Squaring the Circle Between Theory and Evidence, "International Studies Review", vol. 18, no. 2.

Davidson D. (2000), Truth Rehabilitated, in: Rorty and His Critics (Philosophers and their Critics), ed. R. Brandom, Blackwell Publishing, Oxford.

Elman C., Elman M. F. (1997), Lakatos and Neorealism: A Reply to Vasquez, "American Political Science Review", vol. 91, no. 4.

Elman C., Elman M. F. (eds.) (2003), Progress in International Relations Theory. Appraising the Field, MIT Press, Cambridge.

Farber H. S., Gowa J. (1995), Polities and Peace, "International Security", vol. 20, no. 2.

George A. L., Bennett A. (2005), Case Studies and Theory Development in the Social Sciences, MIT Press, Cambridge.

Halliday F., Rosenberg J. (1998), Interview with Ken Waltz, "Review of International Studies", vol. 24, no. 3.

Humphreys A. R. C., (2011), The Heuristic Application of Explanatory Theories in International Relations, "European Journal of International Relations", vol. 17, no. 2.

Jervis R. (1999), Realism, Neoliberalism and Cooperation: Understanding the Debate, "International Security", vol. 24, no. 1.

Katzenstein P. J. (1996), Introduction: Alternative Perspectives on National Security, in: The Culture of National Security: Norms and Identity in World Politics, ed. P. J. Katzenstein, Columbia University Press, New York.

Kay J. (2012), The Map Is Not the Territory: Models, Scientists, and the State of Modern, "Macroeconomics, Critical Review: A Journal of Politics and Society", vol. 24, no. 1.

Keohane R. O. (1984), After Hegemony. Cooperation and Discord in the World Political Economy, Princeton University Press, Princeton. 
King G., Keohane R. O., Verba S. (1994), Designing Social Inquiry. Scientific Inference in Qualitative Research, Princeton University Press, Princeton.

Kratochwil F. (1993), The Embarrassment of Changes: Neo-realism as the Science of Realpolitik without Politics, "Review of International Studies", vol. 19, no. 1.

Lakatos I. (1970), Falsification and the Methodology of Scientific Research Programmes, in: Criticism and the Growth of Knowledge, eds. I. Lakatos, A. Musgrave, Cambridge University Press, New York.

Lakatos I. (1995), Pisma z filozofii nauk empirycznych, Wydawnictwo Naukowe PWN, Warsaw.

Levy J. S. (1989), Domestic Politics and War, in: The Origin and Prevention of Major Wars, eds. R. I. Rotberg, T. K. Rabb, Cambridge University Press, Cambridge.

Maoz Z., Russett B. (1993), Normative and Structural Causes of Democratic Peace, 1946-1986, "The American Political Science Review", vol. 87, no. 3.

Mearsheimer J. J. (2001), The Tragedy of Great Power Politics, W.W. Norton, New York.

Monteiro N. P. (2014), Theory of Unipolar Politics, Cambridge University Press, New York.

Morgenthau H. J. (1959), Theoretical Aspects of International Relations, in: Theoretical Aspects of International Relations, ed. W. T. R. Fox, University of Notre Dame Press, Notre Dame.

Oren I. (1995), The Subjectivity of the "Democratic" Peace, "International Security", vol. 20, no. 2.

Reus-Smit Ch. (2016), Theory, History, and Great Transformations, "International Theory", vol. 8, no. 3 .

Ruggie J. G. (1998), What Makes the World Hang Together? Neo-utilitarianism and the Social Constructivist Challenge, "International Organization", vol. 52, no. 4.

Singer J. D. (1960), Theorizing about Theory in International Politics, "Journal of Conflict Resolution", vol. 4, no. 4.

Singer J. D. (1961), The Level-of-Analysis Problem in International Relations, "World Politics", vol. 14 , no. 1 .

Singer J. D. (1965), Data-Making in International Relations, "Behavioral Science. Journal of the Society for General Systems Research", vol. 10, no. 1.

Vasquez J. A. (1997), The Realist Paradigm and Degenerative versus Progressive Research Programs: An Appraisal of Neotraditional Research on Waltz's Balancing Proposition, "American Political Science Review", vol. 91.

Vasquez J. A. (1998), The Power of Power Politics. From Classical Realism to Neotraditionalism, Cambridge University Press, Cambridge.

Waever O. (2009), Waltz's Theory of Theory, “International Relations”, vol. 23, no. 2.

Wagner R. H. (2007), War and the State. The Theory of International Politics, The University of Michigan Press, Ann Arbor.

Waltz K. N. (1979), Theory of International Politics, Addison-Wesley, Reading.

Waltz K. N. (1986), Reflections on 'Theory of International Politics': A Response to My Critics, in: Neorealism and its Critics, ed. R. Keohane, Columbia University Press, New York.

Waltz K. N. (1993), Evaluating Theory, “American Political Science Review”, vol. 91, no. 4.

Waltz K. N. (2003), Thoughts about Assaying Theories, in: Progress in International Relations Theory. Appraising the Field, eds. C. Elman, M. F. Elman, MIT Press, Cambridge.

Waltz K. N. [2010, (1979)], Struktura teorii stosunków międzynarodowych, Wydawnictwo Naukowe Scholar, Warsaw.

Wendt A. (1999), Social Theory of International Politics, Cambridge University Press, Cambridge.

Wight C. (2002), Philosophy of Social Science and International Relations, in: Handbook of International Relations, eds. W. Carlsnaes, T. Risse, B. A. Simmons, Sage, London. 


\section{Indukcja i dedukcja w teoretyzowaniu stosunków międzynarodowych}

\section{Streszczenie}

W artykule ukazano obecne w nauce o stosunkach międzynarodowych sposoby rozumienia miejsca indukcyjnego i dedukcyjnego wnioskowania w procesie budowania teorii i wiedzy o stosunkach międzynarodowych oraz wynikające z nich spory.

Autor argumentuje, że w badaniu stosunków międzynarodowych, podobnie jak w naukach przyrodniczych, niezbędne jest łączenie empirycznej obserwacji z kreatywnym budowaniem teorii.

Autor dokonuje krytycznej analizy stanowisk wybranych teoretyków stosunków międzynarodowych w kwestiach związanych z problemami indukcji i dedukcji oraz teoretyzowania stosunków międzynarodowych.

Słowa kluczowe: indukcja, dedukcja, teoria, nauka o stosunkach międzynarodowych 